Article

\title{
Inter-Party Conflict Management in Coalition Governments: Analyzing the Role of Coalition Agreements in Belgium, Germany, Italy and the Netherlands
}

\author{
Catherine Moury ${ }^{1}$ and Arco Timmermans ${ }^{2,3}$ \\ ${ }^{1}$ Faculty of Social Sciences and Humanities, New University of Lisbon, Avenida de Berna, 26-C, 1069 Lisbon, Portugal; \\ E-Mail: catherine.moury@fcsh.unl.pt; Tel.: +351217908300 Fax: +351 217908308 \\ ${ }^{2}$ Institute of Public Administration, University of Leiden, Campus The Hague, 2511 VA The Hague, The Netherlands; \\ E-Mail: a.timmermans@cdh.leidenuniv.nl \\ ${ }^{3}$ Montesquieu Institute, 2514 EJ The Hague, The Netherlands
}

\section{How to Cite this Article}

Moury, C., \& Timmermans, A. (2013). Inter-Party Conflict Management in Coalition Governments: Analyzing the Role of Coalition Agreements in Belgium, Germany, Italy and the Netherlands. Politics and Governance, 1(2), $117-131$.

\section{Acknowledgement}

This Article was published by Librello, Politics and Governance's former publisher.

\author{
About the Journal \\ Politics and Governance is an innovative new offering to the world of online publishing in the Political Sciences. An internationally \\ peer-reviewed open access journal, Politics and Governance publishes significant, cutting-edge and multidisciplinary research \\ drawn from all areas of Political Science. \\ www.cogitatiopress.com/politicsandgovernance

\section{Editors-in-Chief} \\ Professor Andrej J. Zwitter, Faculty of Law, University of Groningen, The Netherlands \\ Professor Amelia Hadfield, Department of Psychology, Politics and Sociology, Canterbury Christ Church University, UK

\section{Managing Editor} \\ Mr. António Vieira, Politics and Governance, Cogitatio Press, Portugal
}




\title{
Inter-Party Conflict Management in Coalition Governments: Analyzing the Role of Coalition Agreements in Belgium, Germany, Italy and the Netherlands
}

\author{
Catherine Moury ${ }^{1, *}$ and Arco Timmermans ${ }^{2,3}$ \\ ${ }^{1}$ Faculty of Social Sciences and Humanities, New University of Lisbon, Avenida de Berna, 26-C, 1069 Lisbon, \\ Portugal; E-Mail: catherine.moury@fcsh.unl.pt; Tel.: +351 217908300 Fax: +351 217908308 \\ ${ }^{2}$ Institute of Public Administration, University of Leiden, Campus The Hague, 2511 VA The Hague, \\ The Netherlands; E-Mail: a.timmermans@cdh.leidenuniv.nl \\ ${ }^{3}$ Montesquieu Institute, 2514 EJ The Hague, The Netherlands \\ * Corresponding author
}

Submitted: 15 December 2012 | In revised form: 2 May 2013 | Accepted: 31 May 2013 | Published: 25 July 2013

\begin{abstract}
In this article, we focus on manifest interparty conflict over policy issues and the role of coalition agreements in solving these conflicts. We present empirical findings on the characteristics of coalition agreements including deals over policy controversy and on inter-party conflict occurring during the lifetime of governments in Germany, Belgium, Italy and the Netherlands. We analyze the ways in which parties in government were or were not constrained by written deals over disputed issues. Coalition agreements from all four countries include specific policy deals, one third of which are precisely defined. These policy deals concern both consensual and controversial issues. Our central finding is that, in the case of intra-party conflict, parties almost always fall back on the initial policy deals when these exist. As such, policy statements of the coalition agreement facilitate decision making in each of the countries studied.
\end{abstract}

Keywords: coalition governments; post-electoral coalition agreements; pre-electoral coalition agreements; Belgium; Germany; Italy; Netherlands

\section{Introduction}

Parties that join a coalition want to remain visible to the electorate, but once in office they need to compromise with their partners to pass policies. This co- operation is inherently risky because parties might have to support policies passed by the government that are different from the policies they defended during the election campaign. To reduce uncertainty and facilitate political deals with partners, party leaders 
forming a new coalition government often negotiate a coalition agreement. A coalition agreement is a written document containing policy intentions endorsed by the party organizations before government inauguration. Because they are often drafted under conditions that facilitate compromise, party leaders can agree on more policy deals than they would otherwise, and by producing broad packages the results also become more acceptable to the MPs, the rank and file and the voters of the coalition parties. Our central hypothesis in this contribution is that coalition agreements include enforceable policy deals that help governments resolve conflicts and commit the parties to a particular course of action in decision-making.

While the literature on coalition politics was initially sceptical about these agreements and portrayed policy negotiations in government formation as acts of window dressing [1-3], recent empirical research convincingly shows that coalition agreements contribute significantly to effective coalition governance. For example, it has been demonstrated that coalition agreements are not only quite long and comprehensive (and are getting even longer) [4-6] but also that they contain most of the substance of the government agenda [79] and reduce the likelihood of inter-party conflict during the government's term in office $[8,10-12]$. This empirical work, however, is still very limited in scope and often is confined to two small countries (Belgium, the Netherlands) in which coalitions are composed of parties of similar size that have a long tradition of drafting coalition agreements. Little research has addressed other configurations, such as the combination of a large and a small party, or situations where parties have already drafted a coalition agreement before the election.

To further extend our knowledge of the role of coalition agreements in multiparty politics, we measure the extent to which coalition agreements include policy deals on controversial issues with precise statements. We then analyze a dataset of 114 cases of major interparty conflict and examine the ways in which parties in government referred to deals in coalition agreements made over disputed policies, or experienced conflict over issues not addressed in the coalition agreement. We follow the development of these conflicts from their initial manifestation to the successful or unsuccessful attempts at resolution during the lifetime of the government. Our case studies include governments in Belgium and the Netherlands, two countries with a long practice of coalition agreements, as well as Italy, where coalition agreements are a recent phenomenon and are seen to be low-key, and Germany where governments are sometimes a broad ('grand') coalition but at other times consist of a large and a small party.

The analysis contains eleven governments in countries with institutional differences and where the substance of coalition agreements and ways of coalition conflict management also vary. Given the limited num- ber of cases in this study, we must be cautious when making inferences about what our findings explain. In this article we consider, for countries varying in the configuration in which coalition agreements are made, whether these agreements include concrete policy statements on disputed matters and analyze whether political decision making in the four countries is thus facilitated. In this way we empirically investigate the possible roles of coalition agreements in a more varied context than has been done in coalition research thus far.

\section{The Role of Coalition Agreements: Theoretical Framework and Hypotheses}

Parties joining a coalition come from campaigns during which they emphasized their own profile and often indicated differences in viewpoint with other parties. At the negotiation table, they need to find deals and compromises, but these are risky because they can put the credibility of earlier electoral claims and promises at stake. Governing in coalition can disaffect party members and voters of the party. Parties coming from the opposition, particularly, may have developed 'radical' views and solutions that require a major leap towards compromise with other parties. The words of a former minister and party leader illustrate this tension very well:

"The risk of governing is that a party in government loses members and voters who do not recognise themselves in the actions of the party. (...) It is a very subtle game: the party should not be presenting itself at the following elections as the betrayer of the party spirit. (...) It is a question of a balance between reality and identity." [13]

Party leaders probably face this tension most intensely. They naturally wish to keep their leadership position and hence try to minimize party disunity around their choices [1]. Although party leaders may be put at risk by accepting compromises and package deals, ignoring conflicts or not being able to decide on common policies would certainly go against their longer-term interests. When making each policy decision, party leaders must therefore appraise its intrinsic value; its expected repercussion within the electorate, the parliamentary group and the rank-andfile; and the time and effort which would be needed to obtain an agreement. Party leaders would (instinctively) leave matters if the expected costs of a decision outweigh the benefits; in such cases they may prefer to procrastinate.

As we see it, coalition agreements reduce the costs associated with policy making and enable party leaders to agree on more policy deals than they would otherwise. Party leaders and ministers do not have to negotiate on each single policy independently as 
these are already mentioned in some degree of detail in deals in the coalition agreement. The specific conditions under which coalition agreements are draftedbehind closed doors, in a limited time, addressing multiple issues in parallel-removes public and media pressure and facilitates making compromises and policy packages [14]. Negotiators (including party leaders) are often 'ministerable' and this further enhances the likelihood of agreement and commitment [15].

Consequently, we argue that party leaders engage in negotiations over major and often disputed issues and value the policy deals included in the coalition agreement. We expect that such deals are not just 'everybody happy talk' but are sufficiently substantive and concrete to be enforceable. Parties do address issues that are controversial in government formation because this allows them to be linked to other matters that enhance party and public acceptance and because they are more likely to be manageable later on. This early settlement also helps to make the government less vulnerable to opposition parties trying to attack the government on its weak points.

As we know, coalition agreements are not self-enforcing ([16], p. 582); and ministers are not likely to stick to the original deals if there are no complementary mechanisms constraining their actions. However, we would argue that ministers and MPs have many incentives to comply with the documents. One of these is certainly the MP's and ministers' own ambition. Once in power, ministers would then prefer to avoid appearing being unreliable and disloyal, in order to be renewed in their functions and avoid continuous blaming by their peers. These recent findings are related to the literature on agreements and credible commitment, which argues that actors have incentives to bind themselves to common intentions even if this reduces their leeway in policy making [8]. In other words, if parties spend time and effort making deals over policy issues, some of which may be intensely disputed, they are likely to show a degree of commitment when these deals are on the governmental agenda. As written below, this may be motivated by political morality or be a matter of self-interest and reputation in the coalition game.

Our argument is not new, but the literature on coalition governments contains a strong view that coalition agreements are either quite unsubstantive with just weak commitments $[1,17]$ or that such agreements mostly include points of interparty harmony as opposed to disputed matters [18]. Luebbert [1] considered the drafting of a coalition agreement to be an act of window dressing. His main point was that party leaders are motivated above all by the desire to keep their position and are mainly concerned with minimizing party disunity. As the concrete elaboration of principles always generates dissension, party leaders only include statements in the coalition agreement that are so general that they do not offend anyone. Laver and Shepsle's [17] well known portfolio allocation model is based on the assumption that ministers have exclusive jurisdiction over their area of expertise. Thus, they see coalition building negotiations as 'cheap talk' during which nothing concrete and committing is decided so that coalition agreements are not enforceable.

Recent empirical research, however, shows that coalition agreements do contain matters of pre-existing consensus. One reason for this is that the production of these policy documents in government formation has become institutionalized [6]. They have become a comprehensive type of policy agenda $[6,19]$ and this expanding content includes issues of manifest conflict between coalition parties $[11,12]$. Interviews with (former) ministers also indicate that the reduction of conflict sources and the need to build trust among partners are the main rationales for drafting a coalition agreement. When mistrust is high, agreements become more comprehensive and contain more points on which parties took divergent positions in the election campaign [8]. Another finding is that deals in coalition agreements facilitate and ease decision making $[8,11,12]$, and have a positive effect on the duration of governments [20].

Moreover party leaders can use a range of mechanisms to ensure that ministers (from their own party or a coalition partner) comply with the coalition agreement. Party leaders often know who the minsters they appoint are and are thus in a position to screen and select ministers from their own party not only to ensure as much discipline as possible [21-23] but also to veto the nomination of ministers who have been particularly disloyal to coalition deals in the past [8]. And these party leaders can use tools to be well informed about and to control what their colleagues do. Examples of these mechanisms are intra- and interparty meetings $[12,24]$, Junior Ministers $([16,25]$; but see $[8,26]$ for a different view), parliamentary committees $[18,27]$ and cabinets and their preparatory meetings [8]. Finally, party leaders can also force another minister to act [8], for example by blocking his measures in the cabinet (as in Belgium), by asking parliamentary groups to prepare a motion of censure against them or to draft the legislation themselves (the Netherlands, Germany), or by requesting that the Prime Minister write the proposal himself (Italy, Germany).

This repertoire of coalition governance includes tracking and monitoring the deals in written policy agreements. In Belgian and Dutch governments, for example, deals on disputed issues are made and effectively enforced in most cases, in particular when they are specified [12]. Walgrave et al. [9] compare the attention given to an issue in coalition agreements and the legislation adopted in Belgium. They demonstrate that coalition agreements are good indicators of the legislative agenda. Further, Moury [8] shows that an average of $68 \%$ of the testable statements included in the coalition agreement for eight cabinets in Belgium, Italy, the Netherlands and Germany become formal cabinet decisions and sixty per cent of import- 
ant cabinet decisions are directly traceable to the document.

In sum, the abovementioned literature argues and demonstrates that coalition agreements are an effective mechanism of coalition governance. Because the coalition agreement makes it easier to compromise and reduces agency costs, party leaders not only want ministers to comply with the document but can to a great extent oblige them to do so. In this contribution, we take a slightly different approach to disputed issues and the way they are managed by coalition governments. Instead of concentrating primarily on the coalition agreement or on cabinet decisions, we focus on all major inter-party conflicts emerging during the entire governmental life cycle, from government formation until its termination. We analyze which of this set of disputed issues were included in the coalition agreement and which were not foreseen or were ignored and emerged later. Then we compare how these conflicts were handled during the term of the government. In this way we are able to see whether early deals included in the coalition agreement led to substantive government decisions more (or less) often than cases where no such deals existed and conflicts appeared during the term in office. A focus on interparty conflict is important to the study of coalition governance as policy conflicts are the second most frequent cause of government termination in Western European coalition systems after regular elections [28].

The above mentioned studies inform our contention that, when facing controversy about a policy issue, parties want to refer to a deal included in the coalition agreement when such a deal exists. Parties invest in settling a dispute (or at least begin addressing such matters) at an early stage, so as to begin the course of government with a policy agenda that is as balanced and shared between the partners as possible. Similarly, we expect that controversies already addressed in a coalition agreement are more likely to be followed by governmental policy decisions than disputes between parties not previously placed on the coalition agenda. Such unanticipated or neglected conflicts are more likely to destabilize the coalition and lead to inertia in governmental decision-making. In this way, coalition agreements involve an obligation to produce a result. Even when deals are not precise, or matters in need of political solution are placed on the agenda, coalition members are under increased political pressure to actually find a solution when conflict occurs.

On the basis of this argument we formulate two hypotheses:

H1: If issues disputed during government formation are settled in deals in a coalition agreement, political decisions taken by the government in office are in line with these deals.

H2: Disputes on issues during the term of a government are more likely to be followed by a political decision if the disputed issues were included in the coalition agreement than if the disputes are new to the coalition agenda.

With these two hypotheses, we thus consider the possibility that deals in coalition agreements do not permanently remove all disputes from the coalition life. It is important here to appreciate that the expectation from our first hypothesis is that decisions remain relatively close to the initial deals in the coalition agreement despite recurring conflict. The deals are thus expected to commit the parties even if attempts are made to depart from them. The second hypothesis is a more explicit test of whether deals in coalition agreements actually provide returns on political investments made in government formation; as compared to those deals on which such early political transaction costs were not made. As indicated, parties refraining from negotiating deals on controversial issues in government formation may have either dropped the issues from the agenda or simply not seen them in the first place.

\section{Units of Analysis and Measurement}

This article focuses on the way in which coalition parties make deals over controversial issues and the difference deals included in coalition agreements make to the government's political decision-making. In this section, we present our units of analysis and approach to measurement in order to test our two hypotheses with empirical observations on governments in the four countries under study.

\subsection{Contents of Coalition Agreements}

Our measure of the feasibility of coalition agreements relates to the doability of intentions included in such documents. We build on a technique introduced by Royed [29] and further developed by the Comparative Party Pledge Group (CPPG); we identify feasible statements ('pledges') included in the coalition agreement and distinguish them from more general statements on problems that do not specify how the coalition will try to overcome them. A 'pledge' is defined as 'a commitment to carry out some action or produce some outcome, where an objective estimation can be made as to whether or not the action was indeed taken or the outcome produced' ([29], p. 79). Thus, pledges are testable statements as it is possible to determine whether they have been carried out. We distinguish such pledges from rhetorical statements about policy problems and issues which contain some intention to resolve the problem but leave open how this is to be done. While such statements may contain rhetorical language, they can still be relevant because fleshing out this intention is placed on the coalition agenda, and creates expectations about result (rhetorical statements are something akin to the 'general policy 
language' of legislation, as described by Huber and Shipan [30]).

Pledges can still be more or less precise. Relatively imprecise pledges leave some leeway as to how they are implemented, e.g. the intention to 'reduce income tax' or 'induce immigrants to learn the national language'. Precise pledges contain more concrete actions with less room for manoeuvre, e.g. the intention to 'reduce income tax by three per cent for all employees in the private and public sector in the next budgetary year', and to 'introduce compulsory language courses for all those migrating into the country, beginning on 1 January 2008'. We counted the number of precise and imprecise pledges in order to measure to what extent coalition programs are specific and contain concrete statements.

\subsection{Deals on Major Controversial Issues}

After analyzing the content of coalition agreements, we focus on major interparty conflicts. We consider disputes occurring at any time between government formation and termination as we analyze the degree to which such conflicts were anticipated in coalition agreements or were not foreseen or ignored. We have operationalized a major inter-party conflict as an instance of explicit dispute that involves the mobilization of party branches-ministerial, parliamentary, extraparliamentary-or even entire parties acting en bloc in confrontation with one or more other parties in the coalition. This type of controversy differs from interdepartmental conflicts where ministers are involved primarily as heads of their government department [31]. Interdepartmental conflicts may escalate to interparty conflicts, but they were only counted if this escalation was apparent in our data sources. This approach follows the method used to analyze conflict management arenas in the comparative volume on coalition governments by Strøm et al. [24].

We used national media sources and secondary data [32] to identify major interparty conflicts. All conflicts reported in annual political reports plus all conflicts reported in the weekly press were considered. In addition, a key word search was made in newspaper archives to select only those conflicts that were reported in the national press for more than one day (i.e. lasting several days or recurring at different points in time during the term of the government). This helped us to identify the major disputes on policy issues [33].

We then coded whether the conflict was mentioned in the coalition agreement or first appeared after the government took office. As noted in the previous section, policy controversy during government formation may be settled through deals containing precise or imprecise pledges, or statements that indicate a problem definition and goals but no clear course of action about solutions. Conflicts during the term of the government may arise over statements documented in a coalition agreement or on matters without previous reference. As noted above, unclear commitments that raise expectations may serve as a policy agenda because parties can take them as a starting point that justifies giving the issue attention, and demand that other parties cooperate in elaborating them to more concrete policies to be endorsed by the government. Thus we distinguish such vague commitments in coalition agreements from situations where nothing is mentioned about a disputed issue [34].

\subsection{Role of the Coalition Agreement in Cases of Controversy}

We measure the degree to which parties are committed to the initial deal in the coalition agreement or to flesh out more general intentions on disputed issues by examining manifest inter-party conflicts and the actions and decisions, when taken, during the term in office. Commitment refers to whenever the coalition parties' actions and decisions were faithful to the initial deals and statements in the coalition agreement. Decisions refer to the production of substantive policy output endorsed by the executive and in parliament. This output can be legislation or some other type of policy decision, depending on what was written in the coalition agreement. We want to avoid a static approach to our analysis of commitment. A vague deal followed by renegotiation and a policy decision is also considered a case of commitment as parties elaborate an issue that was placed on the policy agenda. However, a procedural deal that is followed by conflict over what to do or negotiations in these cases lead to renewed stalemate are considered non-commitment to the coalition agreement because they violate the aim of the initial deal, which is primarily about conflict containment and less about policy substance [35]. We distinguish between decisions and non-decisions as two possible results of conflict resolution to compare the outcome of controversies over issues based on the coalition agreement with those that are not [36].

When applying this measurement approach, we acknowledge that the inclusion of a topic in the coalition agreement may not be a necessary condition for a type of conflict resolution and a substantive policy decision to occur. It could be that the policy deal resolving a conflict is simply the common denominator among the coalition parties that they would also have found once the term of the government had begun. In this sense, a certain type of conflict resolution may not depend on the inclusion in the coalition agreement. It may be that similar types of conflict over issues are settled in the same way whether or not this settlement was already delineated in the coalition agreement. In order to address this issue of causal ascription of conflict management to coalition agreements and support our argument that such agreements do have an independent effect, we also present four examples of highly important inter-party conflicts and the role of the coalition agreement in producing an outcome. 


\subsection{Selection of Case Studies}

We analyze eleven governments in four countries: Belgium, Germany, Italy and the Netherlands. These were selected in order to increase the variance and hence check the 'mobility' of our argument. In Belgium and the Netherlands, parties wait for the electoral results before negotiating the government coalition and consequently coalition agreements are made after the vote. Almost all executives taking office in both these countries since the 1960s had a coalition agreement; this policy document increased in size, peaking in 1988 in Belgium with over 40,000 words, and in 1998 in the Netherlands with 36,000 words. The length of coalition agreement has decreased in the past decade, but in both countries agreements continued to be key parts of government formation in which party leaders and prospective ministers were involved. Moreover, empirical research suggests that coalition agreements play an important role in these countries [11,37].

In Germany, all coalitions have been based on postelectoral coalition agreements since the early 1980 s, so later than in Belgium and the Netherlands. But we also observe that the length of these documents has increased considerably: from 1200 words in 1980 to 65,000 words in 2005. German government coalitions usually consist of one of the two major parties and at least one small party, but so-called Grand Coalitions between the Christian Democrats and the Social Democrats were also formed (in 1966-1969 and in 20052009). We include both these types of government. Expectations regarding compliance, however, are ambiguous. On the one hand, decision-making (and thus resolution of deals) is likely to be difficult in Grand Coalitions, because parties must balance stronger ideological differences and are competing more fiercely for votes than a coalition composed of ideologically less diverse parties ([38], p. 41; [39], p. 271; [40], p. 2). On the other hand, in the traditional German coalition type, the major party controls most of the portfolios and thus it might be easier for them to renege on some of their commitments.

Italy seems the least likely case for coalition agreements to have an effect on coalition governance. Italy has a short and recent history of coalition agreements. Although there were many examples of multiparty governments, coalition agreements hardly existed during the First Republic (1947-1992). This changed with the adoption of a new mixed electoral system in 1993, introducing a first-past-the-post system for three quarters of the Senators and Deputies. This induced parties to form a coalition prior to the elections. Since 1996, two coalitions (one center-left, the other center-right) were presented to the voters, including their preferred candidate for the office of prime minister and a common electoral platform which would also serve as the coalition agreement. While these agreements were initially hammered out mostly by political outsiders, party spokespeople have become more involved in recent years. In addition, Italy lacks institutionalized internal arenas for managing interparty disputes. The lack of these internal mechanisms to enforce deals over conflicts makes it harder to secure commitment as it implies a need to change and invent institutional arrangements for negotiation and conflict resolution. These conditions raise the political transaction costs of policy dispute settlement.

With these properties in mind, we selected three coalition governments in Belgium (Dehaene I 1992-1995, Dehaene II 1995-1999, and Verhofstadt I 1999-2003), three in the Netherlands (Lubbers III 1989-1994, Kok I 1994-1998, and Kok II 1998-2002), two in Germany (Schroder II 2002-2005 and Merkel I 2005-2009) and three in Italy during the Second Republic (Prodi I 1994-1996, Berlusconi II 2001-2006, and Prodi II 2006-2008). Whereas the Italian coalition agreements were drafted before the elections, this always happened after the elections in the other three countries. Moreover, the Schroder II government distinguished itself from its Dutch, Belgian and German counterparts by its composition: a large and a small party that had already shown willingness to coalesce during the election campaign (but did not write a formal coalition agreement at this stage [41]). All these governments except Prodi I [42] started with parliamentary majority support in the Lower House. Finally, with the exception of Berlusconi II in Italy [43], these were successive governments. This means that the cases are not independent of each other: governments may have built on the experiences of their predecessors in managing interparty disputes.

Although the number of case studies is limited, we expect this approach to be replicable for other coalition governments in the four countries and in a broader set of countries with government coalitions-thus allowing more analytical generalization beyond the findings we present in this contribution.

\section{Empirical Results: Conflict, Agreement and Coalition Policy}

\subsection{Contents of Coalition Agreements and Controversial Issues}

Table 1 shows the content of coalition agreements of the eleven governments, i.e. their length in words [44] and number of pledges, the number of parties and their general ideological orientation.

In most countries, the length of coalition agreements varies [5] and our cases match this pattern. Although we observe very long coalition agreements with an average of more than 30,000 words, the length of these documents ranges from just from 7,500 to an impressive 92,200 words. As expected, coalition agreements contain a large number of concrete pledges for which implementation can be determined ( 255 on average). They are not composed of merely vague rhetorical statements 
as the 'sceptics' about this mechanism of coalition governance would argue. Moreover, just over one third of these pledges are defined very precisely, containing policy detail.

The number of coalition parties and the ideological profile do not seem to affect the length of coalition agreements or the proportion of testable pledges in any systematic way. However, it should be noted that the two governments prolonging their term in office (Dehaene in Belgium in 1995 and Kok in the Netherlands in 1998) produced longer policy documents than in their first term (this has also been observed for other governments, see [4]). The Prodi II government also seems to testify to this phenomenon of the policy agenda expanding in size and detail as a government takes a second term.

Table 1. Properties of coalition agreements of eleven governments.

\begin{tabular}{|c|c|c|c|c|}
\hline Cabinet & $\begin{array}{l}\text { Parties (number and ideological } \\
\text { orientation) }\end{array}$ & Size & $\begin{array}{c}\text { Nr of } \\
\text { pledges }\end{array}$ & $\begin{array}{l}\text { Very } \\
\text { Precise } \\
(\%) \\
\end{array}$ \\
\hline Dehaene I (1992-1995) & $\begin{array}{l}\text { PS, PSC, SP, CVP } \\
\text { 4, Center-Left }\end{array}$ & 7,500 & 143 & $46(32 \%)$ \\
\hline Dehaene II (1995-1999) & $\begin{array}{l}\text { PS, PSC, SP, CVP } \\
4 \text {, Center-Left }\end{array}$ & 17,350 & 175 & $40(23 \%)$ \\
\hline Verhofstadt I (1999-2003) & $\begin{array}{l}\text { PS, PRL-FDF-MCC, Ecolo, SP, VLD, Agalev } \\
\text { 6, Socialists, Liberals and Greens }\end{array}$ & 14,800 & 198 & $110(55 \%)$ \\
\hline Average & & 13,200 & 172 & $65(38 \%)$ \\
\hline Lubbers III (1989-1994) & $\begin{array}{l}\text { CDA, PvdA } \\
\text { 2, Center-Left }\end{array}$ & 28,450 & 157 & $86(55 \%)$ \\
\hline Kok I (1994-1998) & $\begin{array}{l}\text { PvdA, VVD, D66 } \\
\text { 3, Left, Conservative and Liberals }\end{array}$ & 16,250 & 176 & $76(43 \%)$ \\
\hline Kok II (1998-2002) & $\begin{array}{l}\text { PvdA, VVD, D66 } \\
\text { 3, Left, Conservative and Liberals }\end{array}$ & 36,000 & 244 & $152(62 \%)$ \\
\hline Average & & 26,900 & 192 & $107(58 \%)$ \\
\hline Prodi I (1996-1998) & $\begin{array}{l}\text { DS, PPI, RI, UD, Verdi } \\
\text { 5, Center-Left }\end{array}$ & 41,500 & 274 & $46(17 \%)$ \\
\hline Berlusconi II (2001-2006) & $\begin{array}{l}\text { FI, AN, LN, CDU-UDC } \\
\text { 4, Center-Right } \\
\text { DS, Margherita, Verdi, Italia dei Valori, }\end{array}$ & 9,600 & 312 & $61(18 \%)$ \\
\hline Prodi II (2006-2008) & $\begin{array}{l}\text { MRE, Pci, RC, UDEUR, } \\
\text { Rosa nel pugno } \\
\text { 9, Center-Left }\end{array}$ & 92,200 & 602 & $55(9 \%)$ \\
\hline Average & & 47,800 & 396 & $52(13 \%)$ \\
\hline Schroder II (2002-2005) & $\begin{array}{l}\text { SDP, Greens } \\
\text { 2, Social Democrats + Left }\end{array}$ & 27,200 & 220 & $80(36 \%)$ \\
\hline Merkel I (2005-2009) & $\begin{array}{l}\text { CDU-CSU, SDP } \\
\text { 2, Grand Coalition }\end{array}$ & 52,900 & 297 & $150(51 \%)$ \\
\hline Average & & 40,050 & 259 & $115(44 \%)$ \\
\hline Average (Total) & & 31,988 & 255 & $85(38 \%)$ \\
\hline
\end{tabular}

Abbreviations: PS: Parti Socialiste (French Speaking Socialist Party), PSC: Party Social Chrétien (French Speaking Christian Democratic Party), SP: Socialistiche Partij (Flemish Socialist Party), CVP: Christelijke Volkspartij (Flemish Christian Democratic Party), PRL-FDF-MCC: Parti Républicain Libéral-Front Démocratique des Francophones-Mouvement des Citoyens pour le Changement (French Speaking Alliance of Liberal parties), Ecolo (French Speaking Green Party), VLD: Vlaamse Liberalen en Democraten (Flemish Liberal Party), Agalev (Flemish Green Party), PvdA: Partij van de Arbeid (Labor Party), CDA: Christen Democratisch Appel (Christian Democratic Party), VVD: Volkspartij voor Vrijheid en Democratie (Liberal/Conservative Party), D66: Democrats 1966 (Liberal Democrats), DS: Democratici di Sinistra (Italian Leftist Party), PPI: Parti Populare Italiano (Italian Popular Party), RI: Rinnovamento Italiano (Italian Renewal), UD: Unione Democratica (Demoratic Union), FI: Forza Italia, AN: Alleanza Nazionale (National Alliance), LN: Lega Norte (Northern League), CDU-UDC: Cristiani Democratici Uniti-Unione Christiana Democratica (Italian Christian Democrats), Margherita (center-left party), Verdi (Greens), Italia dei valori (Italy of values), MRE: Movimento Repubblicani Europei (European Republicans), PCI: Partito dei Communisti Italiani (Communists), RC: Rifondazione Communista (Communists), UDEUR: Unione Democratici per l'Europa (left Catholic party), Rosa Nel Pugno (Secular party), SDP: Sozialdemokratische Partei Deutschlands (Social Democrats), CDU: Christlich Demokratische Union Deutschlands (Christian Democrats), CSU: Christlich-Soziale Union in Bayern (Christian Social Union in Bavaria). 
This contradicts the intuition that parties in such governments are more familiar, display a lower level of mistrust and thus feel less need to stipulate policies in advance. Finally, and perhaps less surprisingly, the Grand Coalition in Germany engaged in placing a larger number of precise deals in the coalition agreement than a traditional coalition of a big and a small party.

Overall, the coalition agreements we analyzed include a large number of specific and precise policies. Italian pre-electoral coalition agreements were not shorter or less specific than post-electoral agreements. In fact, the opposite seems true; the preelectoral Prodi II agreement of 2006 stands out for its length: longer than any other agreement in any of the other three countries with a tradition of drafting such agreements. An explanation for this may be that preelectoral agreements also serve as electoral platforms for presenting a range of policy preferences and intentions to the voters. They are therefore expected to include the preferences of the pre-electoral coalition on each issue of interest to the public. Not all these issues were disputed between the parties, nor were they included in precise pledges.

We also observe a large difference between coalition agreements in Italy and the other countries: an average of around 40 per cent precise pledges or more in Belgium, Germany and the Netherlands compared with just 13 per cent in Italy. Just 9 per cent of the pledges in the long Prodi II agreement were very precise. It may be that uncertainty about electoral results and the risk of displeasing voters discouraged parties and negotiators to go into great detail.

\subsection{Early Attention to Controversial Issues in All Countries}

As noted, usually only a part of the coalition agreement is devoted to controversial issues. Many statements and policy pledges involve no real controversy between the partners. We collected data on the most controversial policy problems within the eleven governments throughout their life cycles, i.e. from formation to termination and registered and coded a total of 115 major inter-party conflicts. Table 2 shows the number of conflicts in each government and the policy areas in which these conflicts occurred. It shows that, in relative terms, Belgian governments experienced less manifest conflict than the other governments. This may in part be explained by the strong emphasis on collective responsibility and collegial decisionmaking; ministers are prevented from criticizing decisions once adopted within the Cabinet. Another reason may be that parliament does not really stand as a strong and politically critical institution vis-à-vis the government. Parliamentary party groups rarely initiate conflict and still less when this may evoke coalition tensions. Table 2 also shows that socio-economic and budgetary policy issues have been the most controversial. This stood out most in the Kok I and II co- alitions which excluded the central Christian Democrats and where a considerable policy distance had to be bridged on these issues. It is visible to a lesser extent in the Verhofstadt I government in Belgium ([45], see [46]). In Italy, the proportion of budgetary and socio-economic conflicts is lower; one reason for this may be coalition composition. Although there are marked differences between the parties of the same coalition, especially in the center-left coalition, this was not the main point of disagreement between them. Institutional change and regulatory issues within the field of justice also gave rise to conflict in all our cases except Prodi I and Schroder II. The severe crisis over the national justice system was a key problem in the 1990s in Belgium; in the Netherlands, the call for democratic reforms by D66, the smallest coalition party in Kok I and II, triggered major conflict in the late 1990s; in Italy the State and Justice reform was a source of disagreement and conflicts on health and pension reform appeared to be pre-eminent in Germany.

Morality issues surfaced in the Kok I government in the Netherlands (rules on divorce), and during Berlusconi (genetic modification) and Prodi (civil unions). Other issues on which the religious-secular divide played a part were related to school policy (Kok I government). Our cases therefore show that policy controversies over religious-secular issues never disappeared from the agenda in coalition politics, though they are not as salient as in earlier times in Belgium and the Netherlands.

We next assess whether the emerging conflicts were already addressed in the coalition agreement. Failure to mention issues may have been deliberate or because they were not anticipated. Table 3 presents the number of conflicts for each of the eleven governments, distinguishing between those already mentioned and those not mentioned in the coalition agreement. We also specify whether the coalition agreement was precise on the controversial issues that were included.

Table 3 shows that 74 per cent of all conflicts was on matters already mentioned in the coalition agreement. Agreements therefore mention deals and stipulate courses of action over disputed issues, as we expected. Coalition agreements in Italy were not found to mention these conflicts significantly less often than in Germany, Belgium and the Netherlands. More than two thirds of the conflicts (22 out of 32 cases, 69 per cent) in the three Italian governments were over an issue mentioned in the coalition agreement. Matters of controversy had been referred to in Dutch and German agreements more often (in 88 and 78 per cent of the cases, respectively), but less so in Belgium (in 56 per cent of the cases). We note however that the government which did not anticipate conflict was the one of Dehaene II (1995-1999). This was in office during a period of extraordinary institutional stress after the police and the judicial system had repeatedly failed to arrest and imprison a murderous paedophile (the Dutroux scandal). Although Christian Democrats and Socialists 
were in office together for a second term, the disputes in this government were mostly unforeseen given the unusual circumstances.

With the exception of the Dutch governments, where financial plans are quite specific, a minority of conflicts relate to precise policy deals. It is, however, difficult to determine cause and effect here as precisely defined policy deals might be those that are more consensual; or alternatively consensus might be driven by the ex-ante precise definition of the policy.

\subsection{Role of Coalition Agreements in Cases of Controversy}

Our first hypothesis on conflicts and agreements in the four countries is that coalition parties are committed to deals on issues included in coalition agreements. Commitment concerns loyalty to policy deals and forms of conflict resolution mentioned in the coalition agreement, and it includes the ability to produce formal policy decisions in line with the agreement. We stress again that our focus is on deals resolving an interparty conflict and we do not analyze other issues leading peacefully to decisions that may or not be based on the coalition agreement (see $[7,8]$ for such a broader analysis). In order to see whether this happened, we traced the political follow-up process of these initial deals throughout the term of the government. Table 4 presents our findings on the degree of commitment and the production of policy decisions.

Table 2. Interparty conflicts in policy fields.

\begin{tabular}{|c|c|c|c|c|c|c|c|c|c|}
\hline & $\begin{array}{l}\text { Budget: } \\
\text { revenues } \\
\text { and } \\
\text { spending }\end{array}$ & $\begin{array}{c}\text { Institu- } \\
\text { tional }\end{array}$ & Justice & $\begin{array}{c}\text { Health } \\
\text { and } \\
\text { Pension } \\
\text { Reforms }\end{array}$ & $\begin{array}{c}\text { Environ- } \\
\text { ment }\end{array}$ & $\begin{array}{c}\text { Foreign } \\
\text { Affairs } \\
\text { and } \\
\text { Defence }\end{array}$ & Morality & Others & Total \\
\hline Dehaene I & 3 & 1 & - & - & - & 1 & - & - & 5 \\
\hline Dehaene II & 3 & 2 & 2 & - & - & - & - & - & 7 \\
\hline Verhofstadt I & 2 & 1 & 1 & - & 2 & - & - & - & 6 \\
\hline Lubbers IIII & 3 & - & 1 & 1 & - & 1 & - & - & 6 \\
\hline Kok I & 6 & 2 & - & - & 1 & - & 1 & 1 & 11 \\
\hline Kok II & 5 & 2 & 1 & 1 & - & - & - & - & 9 \\
\hline Prodi I & 3 & 1 & 4 & 1 & - & - & 1 & 1 & 11 \\
\hline Berlusconi II & 3 & 3 & 3 & 1 & - & - & 1 & 3 & 14 \\
\hline Prodi II & 2 & - & - & 1 & - & 2 & 1 & 1 & 7 \\
\hline Schroder II & 2 & - & - & 13 & - & 2 & - & 2 & 19 \\
\hline Merkel I & 2 & 2 & 4 & 5 & 1 & 4 & - & 2 & 18 \\
\hline$\overline{\text { Total }}$ & & & & & & & & & 113 \\
\hline
\end{tabular}

Table 3. Conflicts on issues mentioned and not mentioned in coalition agreement $(N=76)$.

\begin{tabular}{lcccc}
\hline & Conflicts & $\begin{array}{c}\text { Not in coalition } \\
\text { agreement }\end{array}$ & $\begin{array}{c}\text { In coalition } \\
\text { agreement }\end{array}$ & $\begin{array}{c}\text { Precise in coalition } \\
\text { agreement }\end{array}$ \\
\hline Dehaene I & 5 & 1 & 4 & 1 \\
Dehaene II & 7 & 6 & 1 & 0 \\
Verhofstadt I & 6 & 1 & 5 & 1 \\
\hline Sub-total & 18 & $8(44 \%)$ & $10(56 \%)$ & $2(11 \%)$ \\
\hline Lubbers III & 6 & 3 & 3 & 2 \\
Kok I & 11 & 0 & 11 & 6 \\
Kok II & 9 & 0 & 9 & 7 \\
\hline Sub-total & 26 & $3(12 \%)$ & $23(88 \%)$ & $15(58 \%)$ \\
\hline Prodi I & 11 & 5 & 6 & 2 \\
Berlusconi II & 14 & 4 & 10 & 1 \\
Prodi II & 7 & 1 & 6 & $7(22 \%)$ \\
\hline Sub-total & 32 & $10(31 \%)$ & $22(69 \%)$ & 1 \\
\hline Schroder II & 17 & 2 & 15 & 2 \\
Merkel I & 21 & 7 & 14 & $3(8 \%)$ \\
\hline Sub-total & 38 & $9(24 \%)$ & $29(76 \%)$ & $27(24 \%)$ \\
\hline Total & $114(100 \%)$ & $30(26 \%)$ & $84(74 \%)$ & \\
\hline
\end{tabular}


Table 4. Types of result in conflict management $(\mathrm{N}=76)$.

\begin{tabular}{lcccccc}
\hline & \multicolumn{2}{c}{$\begin{array}{c}\text { Conflict over issue included } \\
\text { in agreement }\end{array}$} & $\begin{array}{c}\text { Conflict over issue not } \\
\text { included in agreement }\end{array}$ & \multicolumn{2}{c}{ Total } \\
\cline { 2 - 7 } & Decision & Non-decision & Decision & Non-decision & Decision & Non-decision \\
\hline Dehaene I & 4 & 0 & 1 & 0 & 5 & 0 \\
Dehaene II & 1 & 0 & 4 & 2 & 5 & 2 \\
Verhofstadt I & 5 & 0 & 0 & 1 & 5 & 1 \\
\hline Subtotal & $10(100 \%)$ & $0(0 \%)$ & $5(62 \%)$ & $3(38 \%)$ & $15(83 \%)$ & $3(17 \%)$ \\
\hline Lubbers III & 3 & 0 & 3 & 0 & 6 & 0 \\
Kok I & 10 & 1 & 0 & 0 & 10 & 1 \\
Kok II & 9 & 0 & 0 & 0 & 9 & 0 \\
\hline Subtotal & $22(96 \%)$ & $1(4 \%)$ & $3(100 \%)$ & $0(0 \%)$ & $25(96 \%)$ & $1(4 \%)$ \\
\hline Prodi I & 4 & 2 & 3 & 2 & 7 & 4 \\
Berlusconi II & 9 & 1 & 4 & 0 & 13 & 1 \\
Prodi II & 3 & 3 & 1 & 0 & 4 & 3 \\
\hline Subtotal & $16(73 \%)$ & $6(27 \%)$ & $8(80 \%)$ & $2(20 \%)$ & $24(75 \%)$ & $8(25 \%)$ \\
\hline Schroder II & 15 & 0 & 2 & 0 & 17 & 0 \\
Merkel I & 14 & 0 & 7 & 0 & 21 & 0 \\
\hline Subtotal & $29(100 \%)$ & $0(0 \%)$ & $9(100 \%)$ & $0(0 \%)$ & $38(100 \%)$ & $0(0 \%)$ \\
\hline Total & $77(92 \%)$ & $7(8 \%)$ & $25(83 \%)$ & $5(17 \%)$ & $102(89 \%)$ & $12(11 \%)$ \\
\hline
\end{tabular}

\subsection{Commitments Are Weaker for Minority Governments}

On average, parties committed to a previous deal in 73 out of the 84 cases ( 87 per cent) in which we identified final government endorsement and political implementation of a deal mentioned in the coalition agreement. This evidence supports our hypothesis.

Our findings however also reveal differences between the countries: while most of the deals were implemented in all four countries, governments in Italy displayed a lower degree of commitment than those in Germany, Belgium and the Netherlands. More specifically: Belgian and German policymakers stuck to all deals made, those in the Netherlands had been able to make the most precisely defined deals, and also carried them out almost without exception. By contrast, in Italy, the Prodi I and II governments showed commitment to only half the deals made during government formation. The Berlusconi II government outperformed them in this respect and its enforcement score was only slightly below that of governments in Germany, the Netherlands and Belgium. This government also had the highest number of conflicts, so its performance is remarkable.

Thus, although commitments are weaker in Italy than in other countries, the enforcement problem was particularly acute in the two Prodi governments. A closer look at these governments shows that the major cause of non-commitment was the lack of a parliamentary vote on legislation that had already obtained government endorsement. Data on the legislative process in Italy show that parliament passed only half the bills during the two Prodi governments compared with nearly 90 per cent of the bills during the Berlusconi II government [47-50]. This is explained largely by the minority status of Prodi I and the vulnerable small majority of Prodi II [51]. Another reason for this may be that-contrary to the Netherlands and GermanyMPs in Italy are not involved in drafting the coalition agreement. While this seems less problematic in the case of Belgium, where the Parliament is extremely disciplined, commitments made between parties of the Center-Left Italian coalitions were structurally difficult to enforce. Although we must be cautious in making inferences, it seems that small coalition size was more important as an unfavorable condition for commitment than the pre-electoral status of the coalition agreement. These conditions may be politically connected in these two governments, but our findings on the other Italian government suggest that commitment to a pre-electoral agreement is actually possible.

\subsection{Less Frequent Decisions Taken by Italian Center- Left Governments}

In our second hypothesis, we expect inter-party conflicts related to a deal in the coalition agreement to be followed by a decision more often. Table 5 shows the type of (non-) decisions following an inter-party conflict. In most instances (89 per cent), decisions followed interparty conflict resolution in the four countries. While major interparty conflicts may have delayed the policy process, the governments in charge of these issues managed to overcome the disputes and took policy decisions in most cases. A second ob- 
servation is that decisions were taken predominantly when issues were mentioned in the coalition agreement (92 per cent). When controversy was new and issues were not foreseen, the result of the conflict was a decision in 83 per cent of the cases. Our findings therefore provide some support for our second hypothesis, even though a decision is sought and found in most cases. Though political transaction costs prior to the term of the government thus seem to have paid off, our findings suggest that coalition commitments and mechanisms of conflict resolution extended beyond what was written in the coalition agreement. Our observations suggest that the informal rule of coalition discipline applies more generally, which is in line with recent work on coalition governance ([6], pp. 176-179).

Comparison of the governments in the four countries shows that the political success rate (for adopting a government decision following conflict) was lower in Italy (75 per cent), again mainly in the two Center-Left Prodi governments, than in the Netherlands (96 per cent), Belgium (83 per cent) or Germany (100 per cent). In Belgium, the coalition agreement seems to have made the greatest difference to producing results (100 per cent against 62 per cent), while in Germany none of the conflicts led to decision failure. In the Netherlands, the small difference between matters stipulated in the agreement and those left unmentioned suggests that conflict management mechanisms and coalition discipline are internalized among parties in government; this is also true for issues that were unaddressed or were not anticipated during government formation.

Table 5. Commitment to deals in the coalition agreement $(\mathrm{N}=55)$. This ratio is calculated for cases in which the issue was mentioned in the coalition agreement, for which the $\mathrm{N}$ is 55 observations.

\begin{tabular}{lc}
\hline & Commitment \\
\hline Dehaene I & $4 / 4$ \\
Dehaene II & $1 / 1$ \\
Verhofstadt I & $5 / 5$ \\
\hline Subbtotal & $10 / 10(100 \%)$ \\
\hline Lubbers III & $3 / 3$ \\
Kok I & $10 / 11$ \\
Kok II & $7 / 9$ \\
\hline Subtotal & $20 / 23(87 \%)$ \\
\hline Prodi I & $3 / 6$ \\
Berlusconi II & $8 / 10$ \\
Prodi II & $3 / 6$ \\
\hline Subtotal & $14 / 22(63 \%)$ \\
\hline Schroder II & $15 / 15$ \\
Merkel I & $14 / 14$ \\
Sub-total & $\mathbf{2 9 / 2 9 ( 1 0 0 \% )}$ \\
\hline Total & $\mathbf{7 3 / 8 4 ( 8 7 \% )}$ \\
\hline
\end{tabular}

While we must be cautious in making causal inferences about coalition agreements and policy output, our findings indicate that commitment to deals and substantive decisions in situations of major interparty dispute was more problematic in the Italian coalitions, in particular in the two Center-Left governments that lacked stable majority support. The Italian cases thus show that multiparty governments may develop similar mechanisms of coalition governance to those in countries where this is institutionalized (this complements the recent analysis of Zucchini on the role of governments in legislative agenda setting, see [52]). However, the bottom line for making such mechanisms effective is one of the key rules of democratic government: deals on public policy need a parliamentary majority for political endorsement. If such majorities need to be established from one issue to the next during the term in office, even deals made in coalition agreements prior to the elections are just tentative ways of conflict settlement and commitment.

\section{Coalition Agreements and Conflict Resolution: Four Examples}

In order to examine more closely how correspondence of findings may also point to causality, we present four examples of conflicts within coalitions that are illustrative of the role of the coalition agreement. As stated above, comparing results of conflict for cases included with those not included in a coalition agreement allows us to see how the coalition agreement actually make a difference to streamlining decision making. The examples show that negotiators are loyal to the coalition agreement, even if they have second thoughts or disagree with what is written, and that parties invest in finding a solution if a conflict arises over a policy intention included in the document. If they refrain from such political updating to re-establish consensus, it may lead to the fall of the government.

We first look at the measures taken by the Dehaene I government to reduce the public deficit. This objective was mentioned in the coalition agreement, without a precise definition of how the reduction should take place. In the course of the legislature, poor economic growth made it difficult to meet this objective and the Minister of the Interior, Vande Lanotte (a Flemish speaking Socialist), presented a plan to reduce the deficit in the long term. While the French speaking ministers (Socialists and Christian Democrats) supported the idea, the Flemish Christian Democrat ministers were under pressure from their party organization and fiercely advocated a shorterterm reduction of the deficit. The conflict between the French Speaking Socialists and the Flemish Democrats reached its peak when the former proposed to introduce a crisis tax and the latter the non-indexation of incomes. As no agreement could be reached, Prime Minister Dehaene presented his resignation to the King in March 2003 but it was not accepted. A meet- 
ing was then organised between Dehaene and the party leaders and a compromise was found (largely by selling public assets).

Another relevant example can be found during the Kok II government when the coalition agreement contained the intention to complete a Constitutional revision necessary for a corrective referendum. This Constitutional revision passed through the Chamber with the required two thirds majority but it was vetoed in the Senate due to dissent from a prominent MP from the VVD, one of the coalition parties. This led to the resignation firstly of the Liberal Democrat (D66) Minister Els Borst-Eilers, and then of the whole government. D66 Party leader De Graaf then stated that the bill was based on the coalition agreement and therefore had to be considered a 'governmental affair' that needed immediate settlement. A few weeks later, a compromise was found among party leaders and ministers, and the legislative process to introduce a 'temporary' referendum was restarted and completed. The bill on the referendum now contained a sunset clause, but this appeared sufficient for D66 to carry on in the coalition.

The decision taken by the Grand Coalition to increase the normal retirement age from 65 to 67 years was also both important and controversial. The measure was extremely unpopular, had not figured in any of the election manifestos of either of the two parties, and was not an issue in the election campaign [53]. However, the partners agreed on it in the coalition agreement. As a compromise to the SPD, the coalition agreement also stated that at the beginning of the next decade the legislature would reassess whether the increase in the retirement age was still justified, taking into account labor market conditions and the economic and social situation of the elderly. As noted by a former SPD minister, the measure was very controversial within his party: "It was a part of the coalition agreement and both party conventions approved. But in the Social Democrat party a lot of people were thinking 'we will never do that, we negotiated it, signed it, voted for it, but we will never do it'. Mr Munterferring [the Social-Democratic Minister for Labor and Social Affairs and party chairman] said that it was in the coalition agreement, and that we had to approve it. Doing that, he took a lot of heat from the party". As our interviewee notes, Franz Muntefering indeed took this responsibility and presented his plans increase the retirement age in January 2006. Despite facing protests from both trade unions and important party members, the cabinet agreed on a bill that followed the coalition agreement. This bill subsequently was passed in both Chambers.

Finally, we consider the issue of regionalization ('devolution') included in the coalition agreement of the Berlusconi II government. The relevant bill triggered conflict within majority parties inside the government, but particularly in parliament. The deputies of Allianza Nazionale amended essential points of the text, which were included in the coalition manifesto, and the ministers of Lega Nord threatened to resign as a consequence. Berlusconi then declared that 'devolution is in the programme (...). They (i.e. MPs from Allianza Nazionale) have not understood what risks they were facing. These risks are huge'. Finally, party leaders (who were also ministers) met and agreed not to change the substance of the regionalization program. The text was finally passed in both chambers in October 2004.

\section{Conclusion}

Our empirical findings strongly suggest that coalition agreements are enforceable and commit parties, further discrediting the idea that there agreements are merely pep talk that does not really commit parties in office. Coalition agreements in Germany, Belgium, the Netherlands and also in Italy include substantive and concrete policy statements, one third of which appears to be precise. These agreements also include issues that were controversial during government formation or were considered in need of special attention to avoid inter-party dispute at a later date. Three quarters of all major inter-party conflicts occurring during the term in office of coalition governments were on matters already addressed previously in the agreement. In these instances, the initial deals were important as reference points to help contain the conflict, avoid further escalation, and facilitate the endorsement of political decisions. Substantive results were less frequent in situations when interparty policy controversy was over new issues on the agenda and was not addressed during government formation, but the difference was not as large as expected. Also, when policy conflict was not identified and settled beforehand, decisions were produced in the vast majority of cases ( 83 per cent against 92 per cent when coalition deals existed).

This finding also holds true for Italy as a country where written coalition agreements with substantive content are presented before elections and are a recent phenomenon. Although coalition agreements in Italy are as long as those in the three Northern countries, agreements in the latter countries stipulate policy intentions in greater detail. The inverse relationship between length and precision in Italyextensive packages containing rather general and sometimes even ambiguous deals - may be linked with the pre-electoral status of the coalition agreement. Parties may have fewer incentives to commence costly political transactions before knowing the election results. Unexpectedly, however, a more complete and precise coalition agreement emerged when a coalition was preparing for a second term (Dehaene I and II, Kok I and II) or after a short intermezzo of a different coalition in office (Prodi II). Newly formed coalitions did not produce longer agreements. Prolonging a term in office or restarting after a short intermezzo is thus 
not only a demonstration of mutual trust. Remaining or suspended conflict, unfinished policy trajectories and alleged shortcomings of a previous incomplete coalition agreement are also incentives for parties to negotiate policy before taking office. First empirical work on the attention given to major policy topics in coalition agreements in the Netherlands suggests that prolonging governments considerably changes their focus of attention [19]. Similarly, but perhaps less surprisingly, the Grand Coalition specified a larger number of policy deals that were also more precise than before.

Secondly, our findings provide evidence for the view that when controversy occurs, coalition agreements do commit parties. We found that conflicts were more often settled if there was already a deal in the coalition agreement to refer back to, and in these cases decisions were also mostly in line with what was initially agreed. Additionally, we presented an example for each country that that showed how coalition parties are under the obligation to solve a conflict that arises over an item included in the coalition agreement. Failure to do this may threaten the survival of the government.

However, this evidence is not equally strong for the four countries. The greatest difference in substantive results between issues included and not included in the coalition agreement was found in Belgium. Though unforeseen conflicts ending in stalemate rather than decisions were over matters of exceptional institutional stress in the Dehaene II government, the reference in this country to the agreement as the 'coalition bible' seems well placed [54]. In the Netherlands and Germany, the difference between pre-identified and unforeseen policy conflicts between parties was small or even nonexistent, but we also note that there were few cases of conflict over issues not yet addressed in the coalition agreement. A clearer difference was found between the three governments in Italy. While the Berlusconi II government produced decisions mostly in line with the coalition agreement, the two Center-Left Prodi governments suffered from decision-making inertia. Our case analyses show this was due mostly to the lack of stable support from a parliamentary majority.

These overall results indicate the conditions under which deals in coalition agreements are made and enforced. Contrary to a long held view in coalition research, coalition agreements do contain controversial

\section{References and Notes}

1. Luebbert G. Comparative Democracy. Policymaking and Government Coalitions in Europe and Israel. New York, NY, USA: Columbia University Press; 1986.

2. Klingemann H-D, Hofferbert RI, Budge I. Parties, Policies and Democracy. Westview, USA: Westview Press; 1994. issues and deals made on them. While these deals do not iron out coalition trouble and in fact often become the subject of further tensions between coalition partners, they do commit them. Opportunistic behavior or claims about 'changing circumstances' appear to be contained in coalition arenas for conflict management, and decisions mostly follow the path initially set in the coalition agreement. Accordingly, coalition agreements not only function as early policy agendas of coalition governments, but also indicate a course of action in political decision making.

This contribution gives some preliminary answers and points the way for further empirical analysis of conflict management and agenda setting in coalition governments with agreements. These agreements may be made before or after parliamentary elections, and they may be exposed to conditions of majority or minority support in parliament. When this research is extended to more cases, with variation in independent variables, it may further enhance our understanding of the way in which coalition governance is organized and what are its results from initial agenda setting during coalition formation and throughout the lifetime of governments. As in the Italian cases, parties forming pre-electoral coalitions may avoid detailed predefinition of policies given the uncertainty about electoral results and the risk of displeasing voters with compromises made between parties with different identities. But on the other hand, such pre-electoral agreements involve a more direct mandate than postelectoral agreements, and for this reason they may imply a stronger sense of commitment. Further analysis should then also give more extensive consideration to the effects of varying sizes of parliamentary support, from supermajorities to minority governments. A more specific focus on this would include the analysis of support agreements between coalition parties and opposition parties on single issues or packages of issues. Although it is more than 25 years since Strøm [55] argued that opposition parties can be well placed to influence policy, systematic empirical results to test this proposition are only beginning to appear [56]. The possibilities for further study may be based on the same idea that inspired our present contribution, namely that analysts should address issues throughout the coalition lifecycle in order to understand what coalition governments do. The still growing frequency of coalition governments in Europe provides a wealth of empirical data for such work.

3. Laver MJ, Budge I, editors. Party Policy and Government Coalitions. New York, USA: St. Martins Press; 1992.

4. Moury C. Les ensembles flous pour y voir plus clair: Décoder les caractéristiques des accords de coalition en Europe Occidentale. Revue Internationale de Politique Comparée. 2004;11:10-22.

5. Müller WC, Strøm K, editors. Coalition Govern- 
ments in Western Europe. New York, NY, USA: Oxford University Press; 2000.

6. Müller WC, Strøm K. Coalition Agreements and Cabinet Governance. In: Strøm K, Müller WC, Bergman T, editors. Cabinets and Coalition Bargaining: The Democratic Life Cycle in Western Europe. Oxford, USA: Oxford University Press; 2008. pp. 159-200.

7. Moury C. Coalition government and party mandate. How coalition agreements constrain the ministers. Party Politics. 2011;17(3):385-404.

8. Moury C. Coalition government and Party Mandate: How coalition agreements constrain the ministers. London, UK and New York, USA: Routledge; 2013.

9. Walgrave S, Varone F, Dumont P. Policy with or without parties? A comparative analysis of policy priorities and policy changes in Belgium, 1991 to 2000. Journal of European Public Policy. 2006;13(7):10211038.

10. Timmermans A. Policy Conflicts, Agreements, and Coalition Governance. Acta Politica. 1998;33:409432.

11. Timmermans A. High Politics in the Low Countries. An Empirical Study of Coalition Agreements in Belgium and the Netherlands. Aldershot, UK: Ashgate; 2003.

12. Timmermans A. Standing Apart and Sitting Together. Enforcing Coalition Agreements in Multiparty Systems. European Journal of Political Research. 2006;45(2):263-283.

13. Interview with a former Minister from Luxembourg. 14 June 2006.

14. Peterson RL, De Ridder M, Hobbs JD, McClellan EF. Government formation and policy formulation. Patterns in Belgium and the Netherlands. Res Publica. 1983;25:49-82.

15. Moury C. Common manifestoes and coalition governance: How Italian political leaders missed the window of opportunity. In: Mammone A, Veltri GA, editors. Italy Today: The Sick Man of Europe. London, UK and New York, USA: Routledge; 2010. pp. 34-49.

16. Thies MF. Keeping Tabs on Partners: The Logic of Delegation in Coalition Governments. American Journal of Political Science. 2001;45(3):580-598.

17. Laver M, Shepsle KA. Making and Breaking Governments: Cabinets and Legislatures in Parliamentary Democracies. New York, USA: Cambridge University Press; 1996.

18. Martin LW, Vanberg G. Parliaments and Coalitions. The Role of Legislative Institutions in Multiparty Governance. New York, NY, USA: Oxford University Press; 2011.

19. Timmermans A, Breeman G. The Policy Agenda in Multiparty Government. Coalition Agreements and Legislative Activity in the Netherlands. In: Walgrave S, Green-Pedersen C, editors. From Policy Theory to a Theory of Politics. Chicago, USA: University of Chicago Press; forthcoming.

20. Saalfeld T. Intra-Party Conflict and Cabinet
Survival in 17 West European Democracies, 19451999. In: Benoit K, Giannetti D, editors. Intra-party Politics and Coalition Governments in Parliamentary Democracies. London, UK: Routledge; 2008. pp. 169186.

21. Müller WC. Political Parties in Parliamentary Democracies. Making Delegation and Accountability Work. European Journal of Political Research. 2000;37(3):309-333.

22. Huber JD, Martinez-Gallardo C. Replacing Cabinet Ministers: Patterns of Ministerial Stability in Parliamentary Democracies. American Political Science Review. 2008;102(2):169-180.

23. Strøm K, Müller WC, Smith DM. Parliamentary Control of Coalition Governments. Annual Review of Political Science. 2010;13:517-535.

24. Strøm K, Müller WC, Bergman T, editors. Cabinets and Coalition Bargaining: The Democratic Life Cycle in Western Europe. New York, NY, USA: Oxford University Press; 2008. pp. 269-301.

25. Verzichelli L. Italy: The difficult road towards a more effective process of ministerial selection. In: Dowding K, Dumont P, editors. The Selection of Ministers in Europe: Hiring and Firing. London, UK: Routledge; 2008. pp. 79-100.

26. Merhson C. The Costs of Coalition. Stanford, USA: Stanford University Press; 2002.

27. Kim D-H, Loewenberg G. The Role of Parliamentary Committees in Coalition Governments. Keeping Tabs on Coalition Partners in the German Bundestag. Comparative Political Studies. 2005;38(9):1104-1129.

28. Damgaard E. Cabinet Termination. In: Strøm K, Mülle WC, Bergman T, editors. Cabinets and Coalition Bargaining: The Democratic Life Cycle in Western Europe. New York, NY, USA: Oxford University Press; 2008. pp. 301-327.

29. Royed TJ. Testing the mandate model in Britain and the United States: Evidence from Reagan and Thatcher eras. British Journal of Political Science. 1996;26(1):45-80.

30. Huber JD, Shipan C. Deliberate Discretion? The Institutional Foundations of Bureaucratic Autonomy. Cambridge, UK: Cambridge University Press; 2002.

31. Andeweg RB. Centrifugal Forces and Collective Decision-Making: The Case of the Dutch Cabinet. European Journal of Political Research. 1988;16(2): 125-151.

32. For Germany, a research assistant was hired to code the Spiegel and the Journal German Politics. In the Netherlands, we used the Jaarboek Documentatiecentrum Politieke Partijen (DNPP Groningen), Vrij Nederland and De Groene Amsterdammer. For Belgium, we used the annual Overzicht van het Belgische politieke gebeuren (Res Publica), De Knack and Le Vif L'Express. For Italy, we used Politica in Italia (Il Mulino), Panorama and Espresso.

33. All conflicts reported in the annual political reports were included in the weekly press. For example, during the Dehaene I government, the issue of redu- 
cing the public deficit was very controversial, and mainly opposed Flemish Christian Democrat (CVP) and Walloon Socialists (PS). This conflict was reported in Belgian's annual political journal, and attracted media attention for several months. It was therefore codified as a major interparty conflict. During the same legislature, La Libre Belgique reported that a socialist minister criticized the decision of the CVP minister Leo Delcroix to abolish circumscription. After a few days, the decision was adopted. This was not coded as a major interparty dispute.

34. In the example of the reduction of the public deficit defined above, the conflict was codified as having been mentioned in the coalition agreement, since the Dehaene I coalition agreement refers to the reduction of the public deficit as its primary objective. On the other hand, parliamentarians were divided across party lines for several weeks after the proposal of the Minister Flick (of Prodi I government) to introduce the amnesty of criminals for some offences. No reference could be found to such a proposal in the coalition agreement, and the conflict was codified as not having been previously mentioned in the coalition agreement.

35. For example, the program of the Prodi II coalition (2006-2008) in Italy included the promise to give non-married couples some of the same legal protection and duties that married persons currently enjoy. The issue was very controversial amongst the majority. In February 2007 the government approved a draft law but this was never discussed in Parliament and hence the conflict resolution was codified as not being in line with the coalition agreement.

36. Given our focus on major interparty controversies, government termination is another possible result of attempts to address the issue.

37. Moury C. Italian coalitions and electoral promises: Assessing the democratic performance of the Prodi I and Berlusconi II governments. Modern Italy. 2011;16(1):35-50.

38. Schmitt $H$, Wüst AM. The extraordinary Bundestag election of 2005: The interplay of longterm trends and short-term factors. German Politics \& Society. 2006;24(1):27-46.

39. Dyson K, Saalfeld T. Actors, Structures and Strategies: Policy Continuity and Change under the German Grand Coalition (2005-2009). German Politics 2010;19(3/4):269-282.

40. Clemens C. Lose-Lose Proposition: Policy Change and Party Politics in the Grand Coalition. German Politics \& Society. 2010;28(3):1-24.

41. Golder SN. Pre-electoral coalition formation in parliamentary democracies. British Journal of Political Science. 2006;36(2):193-212.

42. Prodi II won the elections by a narrow majority of votes, securing a parliamentary majority in the lower but not the upper house.

43. In the period from which we were able to se- lect governments, there were no three successive governments with a coalition agreement in Italy.

44. Dutch, French and Italian have the same 'verbosity', i.e. use broadly the same number of words to say the same thing: it takes respectively $1,1.16$, 1.13 and 1.14 pages to say the same thing in English, Dutch, French or Italian.

45. In Belgium, language issues have long been the main 'coalition killer', but this cleavage line has become much less significant in the coalition politics of this country. Thus the recent institutional arrangements of federalization, with their transfer of competences on a number of economic and cultural matters to the regions, seems to pay off in national coalition politics.

46. Deschouwer K. The Decline of Consociationalism and the Reluctant Modernization of Belgian Mass Parties. In: Katz RS, Mair P, editors. How Parties Organize: Change and Adaptation in Party Organizations in Western Democracies. London, UK: Sage; 1994. pp. 80-108.

47. Own calculation from www.senato.it. Obviously, it must be taken into consideration that the two Prodi governments did not last their entire term, and that the executive makes good use of 'Decree laws', 'Delegating laws', and of the vote of confidence.

48. Capano G, Giuliani M. Governing without surviving: An Italian paradox. Journal of Legislative Studies. 2001;7(4):13-36.

49. Vassallo S. Government under Berlusconi: The Functioning of the Core Institutions in Italy. West European Politics. 2007;30(4):692-710.

50. However, it is striking to observe that the proportion of governmental bills passed by the CenterLeft government is much lower than for the government of Berlusconi II.

51. In the Upper Chamber, through which every bill must pass.

52. Zucchini F. Italy: Government Alternation and Legislative Agenda Setting. In: Rasch BE, Tsebelis G, editors. The Role of Governments in Legislative Agenda Setting. London, UK: Routledge; 2011.

53. Haverland $M$, Stiller S. The Grand Coalition and Pension and Health Care Reform. German Politics. 2010;19(3/4):429-445.

54. De Winter L, Dumont P, Timmermans A. Coalition formation and governance in Belgium: Of government gospels, evangelist, followers and traitors. In: Strøm K, Müller W, editors. Coalition Government in Western Europe. New York, NY, USA: Oxford University Press; 2000.

55. Strøm K. Minority Government in Parliamentary Democracies. The Rationality of Nonwinning Cabinet Solutions. Comparative Political Studies. 1984;17(2):199-227.

56. Artés J, Bustos A. Electoral Promises and Minority Governments: An Empirical Study. European Journal of Political Research. 2008;47(3):307-333. 